\title{
Assessment of estrogenic, mutagenic and antimutagenic activity of nemorosone
}

\section{Mariana S. Camargo, ${ }^{1}$ Soraya D. Varela, ${ }^{1}$ Ana Paula S. de Oliveira, ${ }^{1}$ Flávia Ap. Resende, ${ }^{1}$ Osmay Cuesta-Rubio, ${ }^{2}$ Wagner Vilegas, ${ }^{3}$ Eliana A. Varanda ${ }^{*}, 1$}

\author{
${ }^{1}$ Departamento de Ciências Biológicas, Faculdade de Ciências Farmacêuticas, \\ Universidade Estadual Paulista, Brazil, \\ ${ }^{2}$ Instituto de Farmacia y Alimentos, Universidad de La Habana, Cuba, \\ ${ }^{3}$ Instituto de Química, Universidade Estadual Paulista, Brazil.
}

\begin{abstract}
Currently, a wide range of research involving natural products is focused on the discovery of new drugs in many different therapeutic areas. A great number of the synthetic compounds on the market were derived from natural products, especially plants. Nemorosone is the major constituent of the floral resin of Clusia rosea Jacq., Clusiaceae, and in Cuban propolis. In vitro studies have shown cytotoxic activity in this substance against various tumor cell lines, including those resistant to various cytotoxic drugs, whereas it has low cytotoxicity to non-tumoral cells. Therefore, in order to characterize the biological activity of nemorosone, a substance with potential antitumor activity, and in view of preclinical testing of the toxicity of drug candidate compounds, the main aim of this study was to determine the mutagenic and antimutagenic activity of nemorosone by the Ames test, using the strains TA97a, TA98, TA100 and TA102 of Salmonella typhimurium. Secondly, to characterize the estrogenic activity in an experimental recombinant yeast model (Recombinant Yeast Assay) mutagenic activity was observed at in any of the concentrations in any of the test strains. To evaluate the antimutagenic potential, direct and indirect mutagenic agents were used: 4 nitro-o-phenylenediamine (NPD), mitomycin $\mathrm{C}$ (MMC) and aflatoxin B1 (AFL). Nemorosone showed moderate antimutagenic activity (inhibition level $31 \%$ ), in strain TA100 in the presence of AFL, and strong antimutagenic activity in TA102 against MMC (inhibition level $53 \%$ ). Estrogenic activity was observed, with an EEq of $0.41 \pm 0.16 \mathrm{nM}$ at various tested concentrations.
\end{abstract}

Revista Brasileira de Farmacognosia Brazilian Journal of Pharmacognosy 21(5): 921-927, Sep./Oct. 2011

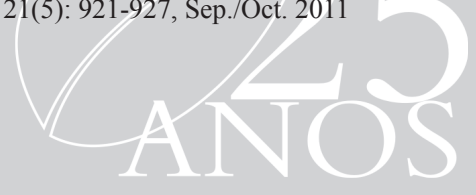

\section{Article}

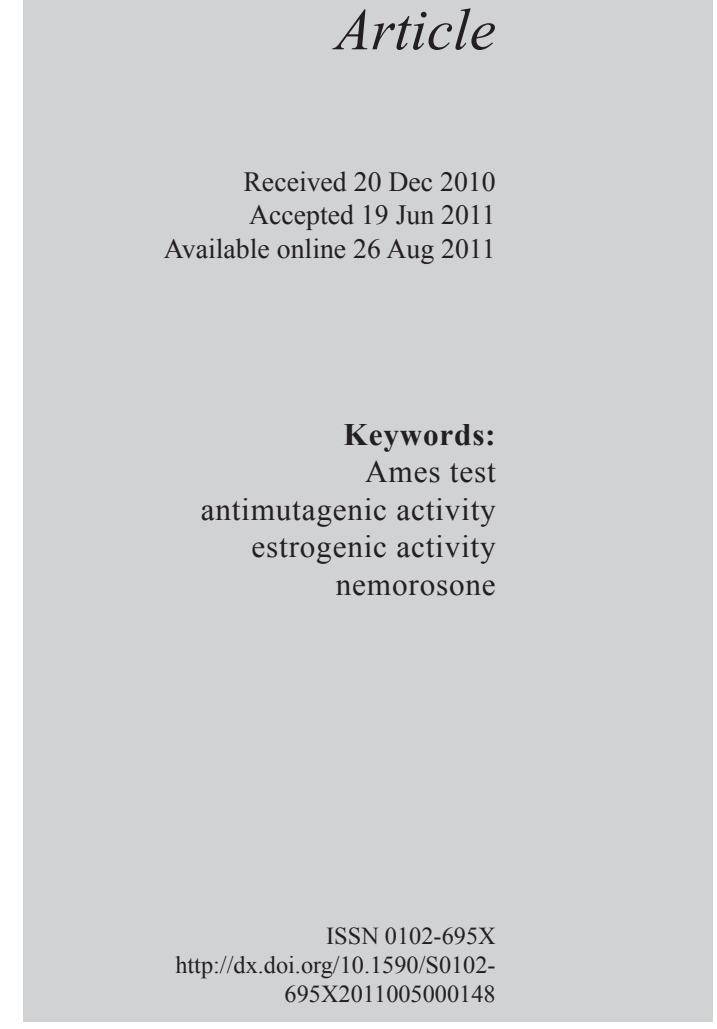

\section{Introduction}

Nemorosone is found in the resin and latex of plants of Clusia (fam. Clusiaceae, syn. Guttiferae) species (Lokvam et al., 2000) and it is the major constituent of Clusia rosea Jacq. floral resins (CuestaRubio et al., 2001; Popolo et al., 2011) and brown Cuban propolis (Cuesta-Rubio et al., 2002; Cuesta-Rubio et al., 2007; Pardo-Andreu et al., 2011). This compound belongs to the class of polycyclic polyisoprenylated benzophenones, a group of acylphloroglucinol derivates wich are characteristic secondary metabolites of the Guttiferae family (Pagano et al., 2008).

The cytotoxicity of nemorosone in several human cancer cell lines has been reported in the past years (Cuesta-Rubio et al., 2002; Diaz-Carballo et al., 2003; Popolo et al., 2011). This compound showed cytotoxic activity in vitro against a range of tumor cell lines, such as breast, colon, ovary, liver and lung carcinoma (including both wild type and chemotherapyrefractory) and it presents low cytotoxicity against normal cell lines (Diaz-Carballo, et al. 2003; DiazCarballo et al.,2008; Popolo et al., 2011). The National Cancer Institute (USA), which considers that a pure compound is active when its IC50 is lower than $4 \mu \mathrm{g}$ / $\mathrm{mL}$ (Cordell et. al., 1993); nemorosone showed IC50 values lower than $3.6 \mu \mathrm{g} / \mathrm{mL}$ against several cancer cell lines (Cuesta-Rubio et al. 2001).

Antineoplastic agents of plant origin, such as vinblastine, vinorelbine, etoposide, teniposide and others, are currently used as parts of anticancer treatment protocols (Bulanas \& Kinghorn, 2005). Phytochemicals have very good prospects as anticancer agents on account of their great chemical diversity and unlimited potential for rational modification (DiazCarballo et al., 2008).

Compounds capable of provoking mutations are found in our daily diet, drinks and medication 
as well as in polluted air and water. It is known that mutations are a major factor for the onset of cancer. However, chemoprevention, that is the prevention of cancer development by chemical substances that act as antimutagenic agents, with the capacity to interact with mutagenic compounds or their metabolites and reduce their effects, is one possible way to prevent cancer (Nogueira et al., 2006; Lira et al., 2008; Chen et al., 2011).

In recent years, endocrine disrupting chemicals (EDC) have become a major issue in the field of environmental science, owing to their ability to interact with human estrogen receptors, thus interfering with the endocrine system (Crews et al., 2000; Brix et al., 2010). Epidemiological studies and animal experiments have shown that estrogen can have carcinogenic properties. Studies to clarify the molecular mechanisms of carcinogenesis by estrogen suggest that estrogen causes carcinogenic effects by combining genotoxicity and stimulation of cell proliferation (Bhat et al., 2003; Cavalieri et al., 2000).

The main aim of this study was to assess the mutagenic and antimutagenic activity of nemorosone by the Salmonella reversion assay, which is widely used for the detection of mutagenic and antimutagenic agents, especially those present in plant extracts. To elucidate further the biological activity of this compound, its estrogenic activity was also tested by recombinant yeast assay.

\section{Materials and Methods}

\section{Chemicals}

Dimethylsulfoxide (DMSO), nicotinamide adenine dinucleotide phosphate sodium salt (NADP), D-glucose-6-phosphate disodium salt, magnesium chloride, L-histidine monohydrate, D-biotin, sodium azide (SAZ), 2-anthramine (2-ANTR), 4-nitro-ophenylenediamine (NPD), mitomycin C (MMC), aflatoxin $\mathrm{B}_{1}$ (AFL), 17ß-estradiol, Triton X-100, SDS $10 \%$, 2-mercaptoethanol, 4-methylumbelliferyl $\beta$-Dgalactoside were purchased from Sigma Chemical Co (St. Louis, USA). Oxoid Nutrient Broth No. 2 (Oxoid, England) and Difco Bacto Agar (Difco, USA) were used as bacterial media.

\section{Plant material}

Flowers of Clusia rosea Jacq., Clusiaceae, were collected in Havana (Cuba) in September 2009 and identified by Dr. Victor Fuentes Fiallo. A voucher specimen (No. 9576) was deposited in the Herbarium of La Estacion Experimental de Plantas Medicinales de Guira de Melena.
Nemorosone was extracted from the floral resins of $C$. rosea and isolated as previously reported (Cuesta-Rubio et al., 2001) In brief, nemorosone was crystallized from floral resins of Clusia rosea employing a mixture of EtOH- $\mathrm{H}_{2} \mathrm{O}$. The product was subject to a VLC on silica gel with $\mathrm{C}_{6} \mathrm{H}_{12}$-EtOAc mixtures to purify it to homogeneity. It was identified through 1-D and 2-D NMR experiments, and its purity was verified by HPLC-DAD and HPLC-MS.

\section{Ames mutagenicity assay}

The Salmonella mutagenicity assay was performed by the pre-incubation method, for 20-30 min with Salmonella typhimurium strains, TA97a, TA98, TA100 and TA102, with and without metabolic activation (Maron \& Ames, 1983). The metabolic activation mixture (S9 mix) was freshly prepared before each test from an Aroclor-1254-induced rat liver fraction purchased (lyophilized) from Moltox Molecular Toxicology Inc. (Boone, NC). S. typhimurium strains were kindly provided by Dr. B. Ames, University of California, Berkeley, CA, USA. The benzophenone was diluted in dimethylsulfoxide and tested at concentrations of 5, 10, 20 and $30 \mu \mathrm{g} /$ plate. The chosen sublethal concentrations were based on the toxicity of the benzophenone to the strains. Toxicity was apparent either as a reduction in the number of his ${ }^{+}$revertants, or as an alteration in the auxotrophic background. The various concentrations of nemorosone to be tested were added to $500 \mu \mathrm{L}$ of buffer (pH 7.4) and $100 \mu \mathrm{L}$ of $S$. typhimurium inoculum. After that, $2 \mathrm{~mL}$ of top agar was added to the mixture and poured on to a plate containing minimal agar. The plates were incubated at $37^{\circ} \mathrm{C}$ for 48 $\mathrm{h}$ and the his ${ }^{+}$revertant colonies were counted manually. The influence of metabolic activation was tested by replacing the buffer with $500 \mu \mathrm{L}$ of S9 mixture (4\%). All experiments were performed in triplicate. The standard mutagens used as positive controls in experiments without S9 mix were 4-nitro-o-phenylenediamine (NPD-10 $\mu \mathrm{g} / \mathrm{plate}$ ) for TA98 and TA97a, sodium azide $(2.5 \mu \mathrm{g} /$ plate $)$ for TA100 and daunomycin $(3 \mu \mathrm{g} / \mathrm{plate})$ for TA102, while 2-anthramine $(0.63 \mu \mathrm{g} /$ plate $)$ was used in the experiments with metabolic activation for TA98, TA100 and TA97a and 2-aminofluorene (10 $\mu \mathrm{g} /$ plate) for TA 102 .

The statistical analysis was performed with the Salanal computer program using the Bernstein model (Bernstein et al., 1982). The data (revertants/plate) were assessed by analysis of variance (ANOVA), followed by linear regression. The mutagenic index (MI) was also calculated for each dose, as the average number of revertants per plate divided by average number of revertants per plate of the negative (solvent) control. A sample was considered positive when $M I \geq 2$ for at least 
one of the tested doses and if the response was dose dependent (Varella et al., 2004; Santos et al., 2010).

\section{Ames antimutagenicity assay}

In accordance with the pre-incubation method, developed by Maron \& Ames (1983), various concentrations of nemorosone were mixed with 100 $\mu \mathrm{L}$ of $S$. typhimurium inoculum and the mutagenic agent (NPD, AFL or MMC), and incubated at $37{ }^{\circ} \mathrm{C}$ for 20-30 min. After this, $2 \mathrm{~mL}$ of top agar was added, supplemented with traces of histidine and biotin, and the content of each tube was lightly homogenized and poured onto a plate of minimal glucose agar. After the top agar solidification, the plates were incubated for $48 \mathrm{~h}$ at $37{ }^{\circ} \mathrm{C}$, and the number of revertant colonies per plate was counted. The entire assay was performed in triplicate. The percentage of mutagenicity inhibition was calculated as in Tachino et al. (1994), where:

$$
\% \text { Inhibition }=1-\frac{\frac{\text { induced revertants }}{\text { plate (with inhibitor) }}}{\frac{\text { induced revertants }}{\text { plate (without inhibitor) }}} \times 100
$$

The antimutagenic effect was considered negligible when a value lower than $25 \%$ was obtained, moderate when a value between $25 \%$ and $40 \%$ was obtained and strong at values greater than $40 \%$ (Neigi et al., 2003).

Cell viability was also determined in each antimutagenesis experiment to assess the bactericidal potential of the mutagens. The responses were considered toxic when sample survival was less than $60 \%$ of the total observed for the negative control (Vargas et al., 1993).

\section{Recombinant yeast assay (RYA)}

Yeast strain BY4741 (MATa ura3 40 leu2 $\Delta 0$ his $3 \Delta 1$ met 15 $\Delta 0$ ) from Euroscarf (Frankfurt, Germany) was transformed with plasmids pH5HE0 and pVitBX2, as described elsewhere (Garcia-Reyero et al., 2001). Expression plasmid pH5HE0 contains the human estrogen hormone receptor HE0 (Green \& Chambon, 1991) cloned into the constitutive yeast expression vector pAAH5. The reporter plasmid pVITB2x contains two copies of the pseudopalindromic estrogen responsive element ERE2 from $X$. laevis vitellogenin Blgene (5'AGTCACTGTGACC-3') inserted into the unique $K p n$ I site of pSFL $\Delta-178 \mathrm{k}$ (Garcia-Reyero et al., 2005). In brief, transformed yeast cells were first grown overnight in non-selective medium (YPD) at $30{ }^{\circ} \mathrm{C}$.
Next, they were grown overnight in minimal medium (6.7 g/L yeast nitrogen base without amino acids, Difco, Basel, Switzerland; 20 g/L glucose, supplemented with $0.1 \mathrm{~g} / \mathrm{L}$ of prototrophic markers as required). The final culture was adjusted to an optical density (OD) of 0.1 and distributed in a siliconized 96-well polypropylene microtiter plate. Aliquots of $10 \mu \mathrm{L}$ nemorosone solution at a final concentration giving $15 \mu \mathrm{g} /$ well were added to $90 \mu \mathrm{L}$ of yeast culture and these initial inoculum were used for subsequent serial dilutions $(1: 10,1: 30$, $1: 90,1: 270$ and 1:810). Positive controls were made by adding $17 ß$-estradiol at a final concentration of 10 nM. For a toxicity control, $10 \mathrm{nM} 17 ß$-estradiol was added to a sample with a dilution factor of 1:30. Plates were incubated for $6 \mathrm{~h}$ at $30{ }^{\circ} \mathrm{C}$ under mild shaking. After incubation, $50 \mu \mathrm{L}$ of the yeast cells lysis reagent Y-PER $^{\mathrm{TM}}$ (Pierce $^{\mathrm{TM}}$, Rockford, IL, USA) was added to each well and further incubated at $30{ }^{\circ} \mathrm{C}$ for $30 \mathrm{~min}$. Finally, $50 \mu \mathrm{L}$ of assay buffer was added to the lysed cells. The assay buffer was prepared by mixing $100 \mathrm{~mL}$ Z-buffer, $1 \mathrm{~mL}$ Triton X-100, $1 \mathrm{~mL} \mathrm{10 \%} \mathrm{SDS,} 70 \mu \mathrm{L}$ 2-mercaptoethanol and $21 \mathrm{mg}$ 4-methyl umbelliferyl-ßD-galactoside. Z-Buffer is a mix of: $60 \mathrm{mM} \mathrm{Na} 2 \mathrm{HPO} 4$, $40 \mathrm{mM} \mathrm{NaH} \mathrm{PO}_{4}, 10 \mathrm{mM} \mathrm{KCl}$ and $1 \mathrm{mM} \mathrm{MgSO}_{4}, \mathrm{pH}$ 7.0 .

After brief centrifugation, plates were read in a spectrofluorometer (Tecan SpectraFluor Plus), set at $355 \mathrm{~nm}$ excitation and $460 \mathrm{~nm}$ emission. Fluorescence was recorded for $20 \mathrm{~min}$ (one measurement per min); ß-galactosidase activity was calculated as rate of the increase in arbitrary fluorescence units per min, using standard linear regression methods. Estrogenicity values are reported as $\mathrm{nM}$ concentration (in the sample) equivalent to $17 ß$-estradiol (EEQ). These values were calculated by adjusting $ß$-galactosidase values from serial dilutions of each sample to the Hill equation by nonlinear methods (Noguerol et al., 2006). The entire assay was performed on four replicates.

\section{Results and Discussion}

The explosive growth of phytotherapy has created a new awareness of the potential value of natural products as anticancer agents (Diaz-Carballo et al., 2003). It may be hoped that, if nemorosone can be developed into a clinical drug in the future, it would prove valuable in both first and second-line therapies (Diaz-Carballo et al., 2008).

Tumor cells possess the characteristic of proliferating much faster than normal cells, so cell proliferation is used as one of the targets for the development of chemotherapeutic agents (Green et al., 2011). These drugs however, when administered to patients, may kill normal cells and thus result in debilitating side effects (Keyomarsi \& Pardee, 2003; 
Brumlik et al., 2008).

Most anti-tumoral agents are designed to action cell proliferation (Green et al., 2011) and apoptosis induction (Peng et al., 2003). Drugs inhibit DNA synthesis by two mechanisms that are generally associated: the drug either binds to DNA by intercalation and stops the replication (Liu et al., 2011); or interferes directly with molecules required for DNA polymerization and/or initiation of replication (Pommier et al., 1998; Bruning \& Mylonas et al., 2011). The ability of such drugs to intercalate into DNA can induce mutations in normal cells (Hoffmann et al., 2003). The accumulation of several random mutations can lead to aberrations in the cells and conversion of non-carcinogenic cells into carcinogenic cells (Ferguson \& Denny, 1995; Raynaud et al., 2008). Thus it is essential that chemotherapeutic drugs be carefully tested not only for anticancer or antitumor activity, but also for their potential mutagenicity (Narayan et al., 2005).

The Ames test is used worldwide as an initial screen to determine the mutagenic potential of new chemicals and drugs. The test is also used to furnish data for submission to regulatory agencies, for the registration or acceptance of many chemicals, including drugs and biocides. International guidelines have been developed for use by corporations and testing laboratories, to ensure uniformity of testing procedures (Mortelmans \& Zeiger, 2000).

In this study, the mutagenicity of nemorosone was assessed by the Ames test, using four different concentrations of the compound and four bacterial strains (Salmonella typhimurium TA97a, TA98, TA100 and TA102), each strain carrying different mutations in various genes in the histidine operon. A metabolic activation system (S9 mix) was added to $S$. typhimurium during the assay to metabolize the nemorosone by the cytocrome P450, enzymes extracted from rat liver. The results show that nemorosone did not induce any increase in the number of revertant colonies, indicating the absence of mutagenic activity. The results for mutagenic activity of nemorosone are presented in Table 1 , showing the number of revertants/plate, the standard deviation and the mutagenic index (MI) after treatment with this benzophenone. The mutagenic index (MI) was not higher than 2 at any tested concentration.

Given that oxidative stress is strongly implicated in the toxicity of chemotherapy, much effort has been focused on the research of diverse antioxidants as potential chemoprotective agents. Tzanova et al. (2009) demonstred the low toxicity of benzophenones to three cell lines and potent destruction of reactive oxygen species generated by tert-butyl hydroperoxide (tBHP). Interestingly, one of the investigated benzophenones was shown to protect non-cancerous cells against tBHP-induced death.

The antimutagenic activity of nemorosone was also assessed by the Ames test and the results are displayed in Table 2. The benzophenone was tested in association with direct (NPD and MMC) and indirect mutagens (AFL) using strains TA98, TA102 and TA100, respectively. When strain TA98 was used in association with NPD was used, no reduction in the number of revertant colonies was observed. For strain TA100, a moderate protective effect was observed when tested with AFL (31\% inhibition). However, in strain TA102, nemorosone showed a strong protective effect when tested with MMC (53\% inhibition). Mitomycin $\mathrm{C}$ is a well known anti-tumor drug whose genotoxic effects in non-tumor cells are of special significance, owing to the possibility that it may induce secondary tumors in cancer patients (Aydemir et al., 2005). It is quite possible that plants and their components may modulate the genotoxicity of anticancer drugs and thus may reduce the chances of cancer patients developing secondary tumors (Siddique et al., 2009). The present results show that nemorosone can reduce the mutagenic damage of one anti-cancer drug therapy (mitomycin C) reducing the probability of secondary tumors being induced in the cancerous patients treated with this drug.

Table 1. Mutagenic activity expressed as the mean and standard deviation of the number of revertants and mutagenic index (in brackets) in strains TA98, TA100, TA102 and TA97a exposed to nemorosone at various doses, with (+S9) or without (-S9) metabolic activation.

\begin{tabular}{|c|c|c|c|c|c|c|c|c|}
\hline \multirow{3}{*}{$\begin{array}{l}\text { Treatment } \\
\mu \mathrm{g} / \mathrm{plate}\end{array}$} & \multicolumn{8}{|c|}{ Revertants/plate in S. typhimurium strains } \\
\hline & \multicolumn{2}{|c|}{ TA98 } & \multicolumn{2}{|c|}{ TA100 } & \multicolumn{2}{|c|}{ TA102 } & \multicolumn{2}{|c|}{ TA97a } \\
\hline & $-S 9^{\mathrm{a}}$ & $+\mathrm{S} 9^{\mathrm{b}}$ & $-\mathrm{S} 9^{\mathrm{c}}$ & $+\mathrm{S} 9^{\mathrm{b}}$ & $-S 9^{d}$ & $+\mathrm{S}^{\mathrm{e}}$ & $-S 9^{\mathrm{a}}$ & $+\mathrm{S} 9^{\mathrm{b}}$ \\
\hline DMSO & $32.3 \pm 3$ & $33.7 \pm 2.3$ & $214.7 \pm 14.3$ & $166 \pm 10$ & $196.67 \pm 11.5$ & $285 \pm 67$ & $123.2 \pm 6$ & $221.3 \pm 2.3$ \\
\hline 5 & $42 \pm 2(1.2)$ & $37.7 \pm 3.5(1.1)$ & $183.7 \pm 14.1(0.8)$ & $163 \pm 9.5(1)$ & $176 \pm 15.7(0.9)$ & $291 \pm 35(1)$ & $112.4 \pm 18(0.9)$ & $243.7 \pm 3.5(1.1)$ \\
\hline 10 & $35.7 \pm 8(1.1)$ & $35.7 \pm 3.2(1.1)$ & $226 \pm 11.5(1.2)$ & $200 \pm 4(1.2)$ & $199.67 \pm 5(1)$ & $324 \pm 8(1.1)$ & $158 \pm 1(1.3)$ & $260.7 \pm 3.2(1.1)$ \\
\hline 20 & $44.3 \pm 13(1.3)$ & $31.8 \pm 6.4(0.9)$ & $184.7 \pm 8(0.8)$ & $176 \pm 14(1.1)$ & $173.3 \pm 25.7(0.9)$ & $295 \pm 29(1)$ & $139.4 \pm 12(1.1)$ & $236.7 \pm 6.4(0.9)$ \\
\hline 30 & $26.08 \pm 16(0.8)$ & $26.3 \pm 2(0.8)$ & $219.7 \pm 23.3(1)$ & $159 \pm 20(1)$ & $203 \pm 29.3(1)$ & $255 \pm 33(0.9)$ & $153.4 \pm 22(1.2)$ & $170.1 \pm 2(0.8)$ \\
\hline Control + & $2150 \pm 720$ & $1107 \pm 23$ & $2734 \pm 53$ & $1241 \pm 53$ & $1496 \pm 190$ & $1338 \pm 33 a$ & $782 \pm 72$ & $1277 \pm 33$ \\
\hline
\end{tabular}

DMSO: $75 \mu \mathrm{L} /$ plate(negative control); Control+Positive control: ${ }^{4} 4-N i t r o-o$-phenylenediamine(NPD-10 $\left.\mu \mathrm{g} / \mathrm{plate}\right)$; ${ }^{\mathrm{b}} 2$-anthramine (0,63.g/plate); ${ }^{\mathrm{c} S o d i u m}$ azide, $(2.5 \mu \mathrm{g} /$ plate); ${ }^{\mathrm{d} D a u n o m y c i n}(3.0 \mu \mathrm{g} / \mathrm{plate}) ;{ }^{\mathrm{e}} 2$-aminofluorene $(10 \mu \mathrm{g} / \mathrm{plate})$. 
Table 2. Antimutagenic activity expressed as the mean and standard deviation of the number of revertants and percent inhibition (in brackets) by nemorosone of direct (-S9) and indirect $(+$ S9) mutagens, in strains TA98, TA100 and TA102 of $S$. typhimurium.

\begin{tabular}{cccc}
\hline $\begin{array}{c}\text { Treatment } \\
\mu \mathrm{g} / \mathrm{plate}\end{array}$ & TA98 & TA100 & TA102 \\
\hline & NPD & Aflatoxin & Mitomycin C \\
Control+ & $972 \pm 20$ & $1376.3 \pm 30$ & $2105.7 \pm 42.3$ \\
2.5 & $936.7 \pm 27(3.6)$ & $1255.7 \pm 37(8.7)$ & $2072.7 \pm 34.5(1.6)$ \\
5 & $808.7 \pm 10(16.8)$ & $1278.7 \pm 24(7)$ & $2013.3 \pm 24.2(4.4)$ \\
10 & $808.3 \pm 7.6(16.8)$ & $1307.3 \pm 21(5)$ & $2063.8 \pm 28.4(2)$ \\
20 & $816.7 \pm 19(14)$ & $1045 \pm 19(24)$ & $1803.4 \pm 9.9(14.3)$ \\
30 & $815 \pm 24(16.2)$ & $940 \pm 20(31)$ & $990.6 \pm 11.1(53)$ \\
\hline
\end{tabular}

Control+ - Positive Control: NPD - 4-nitro-o-phenylenediamine $(10 \mu \mathrm{g} /$ plate)(-S9); Aflatoxin B1 (0.5 $\mu \mathrm{g} /$ plate) $(+\mathrm{S} 9)$; Mitomycin C $(0.5 \mu \mathrm{g} /$ plate)(-S9).

The possible health risks and benefits associated with the consumption of plant estrogens underline the need to characterize the estrogenic potency of vegetables and seeds commonly present in the diet or used as medicinal plants (Agradi at al., 2002).

The estrogenic activity of nemorosone, evaluated by the recombinant yeast assay (RYA) based on vertebrate estrogen receptors, is a convenient measure of the potential for endocrine disruption of a substance or an environmental sample (Garcia-Reyero et al., 2005; Brix et al., 2010). This assay makes use of an engineered yeast strain that harbors two foreign genetic elements: a vertebrate receptor, in this case, a human estrogen receptor, ER, and a reporter gene whose expression is made dependent on the presence of estrogens and whose final product concentration is easy to measure. This is a simplified version of the mechanism by which natural estrogens operate in vertebrates. The fundamental similarity of the transcriptional machinery in all eukaryotes ensures that it also works in yeast, in a similar way.

In breast carcinoma, the estrogen receptor (Er $\alpha$ ) is present in $75 \%$ of cases (Popolo et al., 2011). The phytoestrogens interact with these receptors inducing cancerous cell proliferation (Karayiannakis et al., 1996). The estrogenicity of nemorosone was assessed at various concentrations $(0.19-15 \mu \mathrm{g} /$ well) by RYA and the compound exhibited $0.41 \mathrm{nM} \pm 0.16$ EEq. Figure 1 shows plots of the increase in fluorescence at in different concentrations of the benzophenone and methanol (negative control) against time (for $20 \mathrm{~min}$ ). There are no significant differences between slopes of the nemorosone linear plots and the negative control. Figure 2 shows the mean $\beta$-galactosidase activity, in fluorescence units, induced by nemorosone and the negative control, plotted against dilution factor.

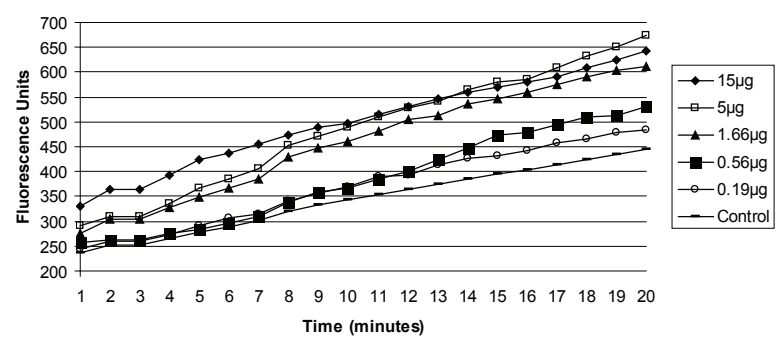

Figure 1. Plots of the increase in fluorescence (in fluorescence units) with time for various nemorosone concentrations and negative control in the RYA system. Concentrations of nemorosone are indicated on the right margin. ß-galactosidase activity was calculated from the slopes of lines fitted to the data by standard linear regression methods. Values are means of four experiments performed in triplicate.

These results shows that nemorosone, at various concentrations, has no estrogenic activity detectable by this method but does possesses a protective activity against some kinds of induced mutation.

Further studies should be performed to assess the biological activity of this benzophenone and clarify its mechanism of action.

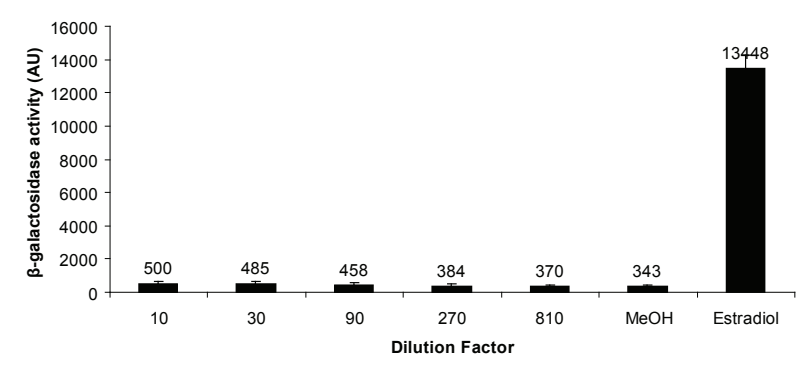

Figure 2. Dose/response plot for various nemorosone dilutions, 17ß-estradiol and negative control (methanol) in the RYA system. The graph shows mean the $\beta$-galactosidase activity in fluorescence units for each nemorosone dilution, from four experiments performed in triplicate.

\section{References}

Agradi E, Fico G, Cillo F, Francisci C, Tomè F 2002. Estrogenic activity of Nigella damascena extracts, evaluated using a recombinant yeast screen. Phytother Res 16: 414-416.

Aydemir N, Celikler S, Bilalouglu R 2005. In vitro genotoxic effects of the anti-cancer drug gemcitabine in human lymphocytes. Mutat Res 582: 35-41.

Bhat HK, Calaf G, Hei TK, Loya T, Vadgama JV 2003. Critical role of oxidative stress in carcinogenesis. Proc Natl Acad Sci 100: 3913-3918.

Bernstein L, Kaldor J, McCann J, Pike MC 1982. An empirical approach to the statistical analysis of mutagenesis data from the Salmonella test. Mutat Res 97: 267-281.

Brix R, Noguerol TN, Piña B, Balaam J, Nilsen AJ, Tollefsen KE, Levy W, Schramm KW, Barceló D 2010. Evaluation of the suitability of recombinant yeast- 
based estrogenicity assays as a pre-screening tool in environmental samples. Environ Int 36: 361-367.

Brumlik MJ, Daniel BJ, Waehler R, Curiel DT, Giles FJ, Curiel TJ 2008. Trends in immunoconjugate and ligand-receptor based targeting development for cancer therapy. Expert Opin Drug Deliv 5: 87-103.

Brüning A, Mylonas I 2011. New emerging drugs targeting the genomic integrity and replication machinery in ovarian cancer. Arch Gynecol Obstet 283: 10871096.

Bulanas MJ, Kinghorrn AD 2005. Drug discovery from medicinal plants. Life Sci 78: 431-441.

Cavalieri E, Frenkel K, Liehr JG, Rogan E, Roy D 2000. Estrogens as endogenous genotoxic agents-DNA adducts and mutations. $J$ Natl Cancer Inst Monogr 27: 75-93.

Chen HH, Chiang W, Chang JY, Chien YL, Lee CK, Liu KJ, Cheng YT, Chen TF, Kuo YH, Kuo CC 2011. Antimutagenic constituents of adlay (Coix lachrymajobi L. var. ma-yuen Stapf) with potential cancer chemopreventive activity. J Agr Food Chem, Article in print

Cordell GA, Kinghorn AD, Pezzuto JM 1993. Separation, structure elucidation and bioassay of cytotoxic natural products. In Colegate SM, Molyneux RJ (eds.) Bioactive natural products: detection, isolation and structure determination. Boca Raton: CRC Press, p. 199-200.

Cuesta-Rubio O, Frontana-Uribe BA, Ramírez-Apan T, Cárdenas J 2002. Polyisoprenylated benzophenones in cuban propolis; biological activity of nemorosone. Z Naturforsch 57: 372-378.

Cuesta-Rubio O, Piccinelli AL, Fernandez MC, Hernández IM, Rosado A, Rastrelli L 2007. Chemical characterization of Cuban propolis by HPLC-PDA, HPLC-MS, and NMR: the brown, red, and yellow Cuban varieties of propolis. J Agr Food Chem 55: 7502-7509.

Cuesta-Rubio O, Velez-Castro H, Frontana-Uribe BA, Cardenas J 2001. Nemorosone, the major constituent of floral resins of Clusia rosea. Phytochemistry 57: 270-283.

Crews D, Willingham E, Skipper J K 2000. Endocrine disruptors: present issues, future directions. $Q R e v$ Biol 75: 243-260.

Diaz-Carballo D, Malak M, Freistuhler A, Elmaagacli A, Bardehheuer W, Reusch HP 2008. Nemorosone blocks proliferation and induces apoptosis in leukemia cells. Int J Clin Pharmacol Ther 46: 428-439.

Diaz-Carballo D, Seeber S, Strumberg D, Hilger RA 2003. Novel antitumoral compound isolated from Clusia rosea. Int J Clin Pharmacol Ther 41: 622-633.

Ferguson LR, Denny WA 1995. Anticancer drugs: an underestimated risk or an underutilized resource in mutagenesis. Mutat Res 331: 1-26.

Garcia-Reyero N, Grau E, Castillo M, López de Alda M, Barceló D, Piña B 2001. Monitoring of endocrine disruptors in surface waters by the yeast recombinant assay. Environ Toxicol Chem 20: 1152-1158.

Garcia-Reyero N, Piña B, Grimalt J O, Fernández P, Fonts R, Polvillo O, Martrat B 2005. Estrogenic activity in sediments from European mountain lakes. Environ
Sci Technol 39: 1427-1435.

Green S, Chambon P 1991. The estrogen receptor: from perception to mechanism. In: MG Parker, Ed., Nuclear Hormone Receptors, Academic Press, London, p 1538.

Green MR, Woolery JE, Mahadevan D 2011. update on aurora kinase targeted therapeutics in oncology. Expert Opin Drug Discov 6: 291-307.

Karayiannakis AJ, Bastounis EA, Chatzigianni EB, Makri GG, Alexiou D, Karamanakos P 1996. Immunohistochemical detection of oestrogen receptors in ductal carcinoma in situ of the breast. Eur J Surg Oncol 22: 578-582.

Hoffmann GR, Calciano MR, Lawless BM, Mahoney KM 2003. Frameshift mutations induced by three classes of acridines in the lacZ reversion assay in Escherichia coli: potency of responses and relationship to slipped mispairing models. Environ Mol Mutagen 42: 111121.

Keyomarsi K., Pardee AB 2003. Selective protection of normal proliferating cells against the toxic effects of chemotherapeutic agents. Progr Cell Cycle Res 50: 527-532.

Lira WD, Santos FV, Sannomiya M, Rodrigues CM, Vilegas W, Varanda EA 2008. Modulatory effect of Byrsonima basiloba extracts on the mutagenicity of certain direct and indirect-acting mutagens in Salmonella typhimurium assays. J Med Food 11: 111-119.

Liu Y, Kumar A, Depauw S, Nhili R, David-Cordonnier MH, Lee MP, Ismail MA, Farahat AA, Say M, ChackalCatoen S, Batista-Parra A, Neidle S, Boykin DW, Wilson WD 2011. Water-mediated binding of agents that target the dna minor groove. J Am Chem Soc 133: 10171-10183.

Lokvam J, Braddock JF, Reichardt PB, Clausen TP 2000. Two polyisoprenylated benzophenones from the trunk latex of Clusia grandiflora (Clusiaceae). Phytochemistry 55: 29-34.

Maron DM, Ames BN 1983. Revised methods for the Salmonella mutagenicity test. Mutat Res 113: 173215.

Mortelmans K, Zeiger E 2000. The Ames Salmonellal microsome mutagenicity test. Mutat Res 455: 29-60.

Narayanan R, Tiwari P, Inoa D, Ashok BT 2005. Comparative analysis of mutagenic potency of 1-nitro-acridine derivatives. Life Sci 77: 2312-2323.

Neigi PS, Jayaprakasha GK, Jena BS 2003. Antioxidant and antimutagenic activities of pomegranate peel extracts. Food Chem 80: 393-397.

Nogueira ME, Passoni MH, Biso FI, Longo MC, Cardoso CRP, Santos LC, Varanda EA 2006. Investigation of genotoxic and antigenotoxic activities of Melampodium divaricatum in Salmonella typhimurium. Toxicol in Vitro 20: 361-66.

Noguerol TN, Boronat S, Casado M, Raldúa D, Barceló D, Piña B 2006. Evaluating the interactions of vertebrate receptors with persistent pollutants and antifouling pesticides using recombinant yeast assays. Anal Bioanal Chem 385: 1012-1019.

Pagano B, Pavone M, Piccinelli AL, Rastrelli L, CuestaRubio O, Mattia CA, Barone V 2008. Structural 
and conformational investigation of nemorosone: a combined X-ray and quantum mechanical study. Chem Phys Lett 462: 158-163.

Pardo-Andreu GL, Nuñez-Figueredo Y, Tudella VG, CuestaRubio O, Rodrigues FP, Pestana CR, Uyemura SA, Leopoldino AM, Alberici LC, Curti C 2011. The anticancer agent nemorosone is a new potent protonophoric mitochondrial uncoupler. Mitochondrion 11: 255-263.

Peng JP, Liu LT, Chang HC, Hung WC 2003. Enhancement of chemotherapeutic drug-induced apoptosis by acyclooxygenase-2 inhibitor in hypopharyngeal carcinoma cells. Cancer Lett 201: 157-163.

Pommier Y, Pourquier P, Fan Y, Strumberg D 1998. Mechanism of action of eukaryotic DNA topoisomerase I and drugs targeted to the enzyme. Biochim Biophys Acta 1400: 83-105.

Popolo A, Piccinelli AL, Morello S, Sorrentino R, Osmany CR, Rastrelli L, Aldo P 2011. Cytotoxic activity of nemorosone in human MCF-7 breast cancer cells. Can J Physiol Pharmacol 89: 50-57.

Raynaud CM, Sabatier L, Philipot O, Olaussen KA, Soria JC 2008. Telomere length, telomeric proteins and genomic instability during the multistep carcinogenic process. Crit Rev Oncol Hematol 66: 99-117.

Santos F V, Calvo TR, Colus I M S, Vilegas W, Varanda EA 2010. Mutagenicity of two species of the genus Alchornea measured by Salmonella microsome assay and micronucleus test. Rev Bras Farmacogn 20: 382389.

Siddique YH, Ara G, Beg T, Gupta J, Afzal M 2009. Assessment of cell viability, lipid peroxidation and quantification of DNA fragmentation after the treatment of anticancerous drug mitomycin $\mathrm{C}$ and curcumin in cultured human blood lymphocytes. Exp Toxicol Pathol 62: 503-508.

Tachino N, Guo D, Daswood WM, Yamane S, Larsen R, Dashwood $\mathrm{R}$ 1994. Mechanisms of the in vitro antimutagenic action of chlorophyllin against benzo(a)pyrene: studies of enzyme inhibition, molecular complex formation and degration of the ultimate carcinogen. Mutat Res 308: 191-203.

Tzanova T, Gerova M, Petrov O, Karaivanova M, Bagrel D 2009. Synthesis and antioxidant potential of novel synthetic benzophenone analogues. Eur J Med Chem 44: 2724-2730.

Varella SD, Pozetti GL, Vilegas W, Varanda EA 2004. Mutagenic activity of sweepings and pigments a household-wax factory assayed with Salmonella typhimurium. Food Chem Toxicol 42: 2029-2035.

Vargas VMF, Mota VEP, Henriques JAP 1993. Mutagenic activity detected by the Ames test in riverwater under the influence of petrochemical industries. Mutat Res 45: 319-331.

\section{*Correspondence}

Eliana Aparecida Varanda

Faculdade de Ciências Farmacêuticas, UNESP, Campus Araraquara

Rodovia Araraquara-Jaú, km 1, 14801-902 Araraquara-SP, Brazil

varandae@fcfar.unesp.br

Tel.: +551633016951

Fax: +551633016940 